\title{
被覆アーク溶接継手の疲水強さに及ぼす溶接止端 形状招よび溶接条件の影響についての統計的解析
}

\author{
正員二瓶正 俊* 佐 々 木悦男* \\ 金尾 正 雄* 正員 稲 垣 道 夫*
}

Statistical Analysis for the Influence of the Toe Shapes of the Weld and the Welding

Conditions on the Fatigue Strength of Arc Welded Joints with Covered Electrode

\author{
by Masatoshi Nihei, Member Etuo Sasaki \\ Masao Kanao Michio Inagaki, Member
}

\begin{abstract}
Summary
In order to investigate the relationship between the fatigue strength and the reinforcement shapes for several types of welded joint, the axial load controlled fatigue tests were carried out employing SM 50 B, SM 58 Q and HT 80 QT steel plates. And the relationship above mentioned were analyzed statistically and discussed about each one group and between groupes that were classified according to materials, type of joints, dimensions of joints, etc.

It was found from these analyses that the variance of fatigue strength between several groupes was mainly attributed to the multiple effect of the stress concentration due to reinforcement shapes of the weld, together with the bending stress at the weld toe to the mismatch and the angular distortion of welded joints.

And the influence of welding conditions on the fatigue strength was also discussed and was shown the necessity of investigating the most suitable welding condition to ensure the lowering of the fatigue strength to the minimum value that was caused by the stress concentration at the toe of the weld.
\end{abstract}

\section{記}

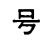

$t:$ 板厚 $(\mathrm{mm})$

$t_{1}:$ リブ厚 $(\mathrm{mm})$

$w$ : 板幅 $(\mathrm{mm})$

$H$ : 突合せ継手の余盛高さ $(\mathrm{mm})$

$l$ :すみ肉継手の脚長 (mm)

$a:$ :と厚 $(\mathrm{mm})$

$\rho:$ 止端半径 $(\mathrm{mm})$

$\theta:$ フランク角(度)

$B:$ 余盛幅 $(\mathrm{mm})$

$L:$ 試験片のグリップ間距輍 $(\mathrm{mm})$

$v_{0}:$ 角変形量 $(\mathrm{mm} / \mathrm{m})$

$\delta:$ 目堂い量 $(\mathrm{mm})$

$\sigma_{w}:$ 時間強さ $\left(\mathrm{N} / \mathrm{mm}^{2}\right)$

$\sigma_{w}^{\prime}$ : 目違い, 角変形による曲げ応力を補正した時間強さ $\left(\mathrm{N} / \mathrm{mm}^{2}\right)$

$\sigma_{w b}$ : 目違い, 角変形による公称曲げ充力 $\left(\mathrm{N} / \mathrm{mm}^{2}\right)$

* 金属材料技術研究所
$Q:$ 止端部汇括怙る余盛最終層の入熱量 $(\mathrm{KJ} / \mathrm{cm})$

$S_{8 / 5}$ : 溶接ボンド部にお括年 $800^{\circ} \mathrm{C}$ から $500^{\circ} \mathrm{C}$ までの 冷却時間 (sec)

$K_{t}:$ 灾力集中俰数

$K_{f}:$ 切欠保数

$K_{f}^{\prime}$ : 目違い,角変形による曲げ応力を補正した切欠倸数 $r:$ 相関保数

\section{1 ま がき}

各㣫棈造物の基本要素である溶接継手の疲れ強さが, その溶接止端部の応力集中により低下することは従来か

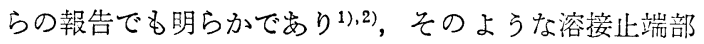
を機械的に，めるいは各種溶接法を用いて滑らかにする ことにより，疲れ強さを向上させようとする研究も数多 く見られる3),4。しかしながら，重要な構造物以外は， まだ止端部を未処理のまま用いることが多く, 溶接継手 の疲れ強さの最大の支配因子であること変わりはな い。また，信頼性工学に基づく設計が主流になりつつあ る現在, 疲れ強さの変動要因について統計的に解析した 
データが必要とされているが，溶接継手に関するその種 のデータは極めて限られているのが実状である。実際の 溶接継手では, その止端形状が溶接線方向に不連続に変 化し，それによる応力集中の溶接線方向での分布も複雑 でありそそれらが溶接継手の疲れ強さのばらつきの一因 になっていると考えられる。

本報告では，溶接継手の疲れ強さの変動に対して最も 重要な因子と考えられる溶接止端形状をとりあげ，溶接 構造用圧延鋼 SM 50 B，SM 58 Q および HT 80 QT の 各種溶接継手について，その溶接止端形状と疲れ強さと の関連を統計的に解析した。また，限定された範囲内で はあるが，溶接条件による止端部形状の変化を介して, 溶接条件の疲れ強さへの影響について子考察し, 疲れ強 さを確保するための最適な溶接条件を考慮する必要性を 示した。

\section{2 試験片および疲れ試験の内容}

供試材としては溶接構造用圧延鋼 SM 50 B，SM 58 Q HT $80 \mathrm{QT}$ 板材を用いた。それらの化学成分の製品分析 值および機械的性質を Table 1 亿示した。溶接施工法 としては，突合せ，リブ十字，十字括よび十字 K開先完 全溶込み溶接継手を作製するため, Table 2 亿示すよう に被覆アーク溶接, 下向姿勢の標準的な溶接条件とした
が，材種ごとに，板厚や継手形状によらずほぼ同一の入 熱条件で行った。溶接長は $300 \sim 600 \mathrm{~mm}$ とし, 溶接後, 所定の寸法に試験片を切り出しているので，溶接残留応 力は注注解放されていると考兄られる。また，溶接施工 にあたっては，目違い拈よび角変形を極力小さくするよ らに拘束ジグを用いたが，Table 3 に示すように，これ らの值がいく分大きいものもめった。

疲れ試験片は Fig. 1 に示すようなるので, 継手試験 片では余盛の修正や削除は行わず溶接のままとした。

使用した疲れ試験機は $150 \mathrm{tf}, 20 \mathrm{tf}$ のサーボ型, $30 \mathrm{tf}$ の油圧共振型, $50 \mathrm{tf}$ のローゼンハウゼン型の 4 台で, す べて WES $1102 \mathrm{~K}$ の動的検定を行い, 所要の性能を満 足していた。疲れ試験は軸荷重制御, 最小最大応力比 $R$ $=0$ の片振り引張りで行った。 $1 S-N$ 当たり $8 \sim 12$ 本 の試験片を用い，母材を含めて 57 本の $S-N$ 曲線を作 成した。これらについて, 溶接止端形状と疲れ強さとの 関連を調べるため, Table 3 に示すように母材も含める と 27 条件のグループ分けを行い，以下の検討に用いた。 これらグループ間では, 疲れ強さの平均值の間に $5 \%$ の 危険率で有意な差があっだ),6)。

止端形状の測定に際しては, 疲れ試験前にすべての試 験片について溶接止端形状をあらかじぬシリコンゴムに より型取りし，疲れ試験後それを切断して 20 倍の投影

Table 1 Chemical composition and mechanical properties of tested materials

Chemical composition

\begin{tabular}{c|c|ccccccccccc}
\hline \multirow{2}{*}{ materials } & \multirow{2}{*}{$t(\mathrm{~mm})$} & \multicolumn{10}{|c}{ Element $(\mathrm{wt} 8)$} \\
\cline { 3 - 10 } & & $\mathrm{C}$ & $\mathrm{Si}$ & $\mathrm{Mn}$ & $\mathrm{P}$ & $\mathrm{S}$ & $\mathrm{Ni}$ & $\mathrm{Cr}$ & $\mathrm{Mo}$ & $\mathrm{V}$ & $0_{2}$ & $\mathrm{~N}_{2}$ \\
\hline \multirow{3}{*}{ SM50B } & 9 & 0.167 & 0.33 & 1.47 & 0.022 & 0.011 & 0.01 & 0.01 & 0.01 & 0.027 & 0.0034 & 0.0046 \\
& 20 & 0.166 & 0.33 & 1.45 & 0.021 & 0.011 & 0.01 & 0.01 & 0.01 & 0.026 & 0.0035 & 0.0045 \\
& 40 & 0.179 & 0.33 & 1.48 & 0.022 & 0.012 & 0.01 & 0.01 & 0.01 & 0.027 & 0.0035 & 0.0048 \\
\hline \multirow{2}{*}{ SM58Q } & 9 & 0.141 & 0.27 & 1.32 & 0.024 & 0.007 & 0.01 & 0.01 & $<0.01$ & 0.003 & 0.0034 & 0.0046 \\
& 20 & 0.141 & 0.28 & 1.34 & 0.029 & 0.007 & 0.01 & 0.01 & $<0.01$ & 0.003 & 0.0029 & 0.0041 \\
\hline \multirow{2}{*}{ HT80 } & 9 & 0.129 & 0.31 & 0.91 & 0.015 & 0.002 & 0.91 & 0.50 & 0.43 & 0.041 & 0.0021 & 0.0062 \\
& 20 & 0.116 & 0.31 & 0.91 & 0.015 & 0.002 & 0.89 & 0.50 & 0.43 & 0.040 & 0.0030 & 0.0059 \\
\hline
\end{tabular}

Mechanical properties

\begin{tabular}{|c|c|c|c|c|c|c|c|}
\hline materials & $t(\mathrm{~mm})$ & $\begin{array}{l}\text { Upper yield } \\
\text { stress } \\
\quad\left(\mathrm{N} / \mathrm{mm}^{2}\right)\end{array}$ & $\begin{array}{l}\text { Tensile } \\
\text { strength } \\
\left(\mathrm{N} / \mathrm{mm}^{2}\right)\end{array}$ & $\underset{\left(\begin{array}{l}0 \\
0 \\
0\end{array}\right)}{\text { Elongation }}$ & $\begin{array}{l}\text { Bend } \\
\text { test }\end{array}$ & $\begin{array}{l}\text { Charpy impact } \\
\text { value }(\mathrm{J})\end{array}$ & $\begin{array}{c}\text { Vickers } \\
\text { hardness } \\
\mathrm{H}_{\mathrm{v}}(10)\end{array}$ \\
\hline \multirow{3}{*}{ SM50B } & 9 & 413 & 541 & 25 & Good & 127 & 156 \\
\hline & 20 & 397 & 534 & 31 & Good & 187 & 154 \\
\hline & 40 & 364 & 526 & 35 & Good & 225 & 149 \\
\hline \multirow{2}{*}{ SM58Q } & 9 & 520 & 608 & 28 & Good & - & 201 \\
\hline & 20 & 549 & 637 & 45 & Good & 205 & 206 \\
\hline \multirow{2}{*}{ HT 80} & 9 & 823 & 853 & 26 & Good & - & 280 \\
\hline & 20 & 833 & 872 & 33 & Good & 205 & 292 \\
\hline
\end{tabular}


Table 2 Welding conditions

\begin{tabular}{|c|c|c|c|c|c|c|}
\hline & \multicolumn{4}{|c|}{ SM50B } & \multirow{2}{*}{$\begin{array}{l}\text { SM58Q } \\
\text { butt } w .\end{array}$} & \multirow{2}{*}{$\begin{array}{l}\text { HT80QT } \\
\text { butt w. }\end{array}$} \\
\hline & Butt w. & $\begin{array}{l}\text { Non-load, } \\
\text { cruciform }\end{array}$ & $\begin{array}{l}\text { Load, } \\
\text { cruciform }\end{array}$ & $\begin{array}{l}\text { Load, } \\
\text { cruciform-K }\end{array}$ & & \\
\hline Welding rod & D5016,4mm & D5016,4 mm $\phi$ & D $5016,4 \mathrm{~mm} \phi$ & $\mathrm{D} 5016, \begin{array}{l}9 \mathrm{t} \cdots 3.2 \mathrm{~mm} \phi \\
20 \mathrm{t} \cdots 4 \mathrm{~mm} \phi\end{array}$ & D5816,4 mm $\phi$ & $\mathrm{L}-80,4 \mathrm{~mm} \phi$ \\
\hline Welding position & Flat & Flat & Flat & Flat & Flat & Flat \\
\hline Welding current & $170 \mathrm{~A}$ & $170-180 \mathrm{~A}$ & $170-185 \mathrm{~A}$ & $\begin{array}{r}9 \mathrm{t} \cdots 130 \mathrm{~A} \\
20 \mathrm{t} \cdots 180 \mathrm{~A}\end{array}$ & $160-170 \mathrm{~A}$ & $150-170 A$ \\
\hline Welding speed & $10-20 \mathrm{~cm} / \mathrm{min}$ & $16-26 \mathrm{~cm} / \mathrm{min}$ & $11-28 \mathrm{~cm} / \mathrm{min}$ & $9-22 \mathrm{~cm} / \mathrm{min}$ & $12-16 \mathrm{~cm} / \mathrm{min}$ & $11-18 \mathrm{~cm} / \mathrm{min}$ \\
\hline Arc voltage & $19-23 V$ & $23-25 V$ & $23-26 \mathrm{~V}$ & $23-26 \mathrm{~V}$ & $24-27 V$ & $25-28 V$ \\
\hline Heat input & $15-20 \mathrm{KJ} / \mathrm{cm}$ & $10-18 \mathrm{KJ} / \mathrm{cm}$ & $8-15 \mathrm{KJ} / \mathrm{cm}$ & $\begin{array}{r}9 \mathrm{t} \cdots 9-13 \mathrm{KJ} / \mathrm{cm} \\
20 \mathrm{t} \cdots 13-18 \mathrm{KJ} / \mathrm{cm}\end{array}$ & $17-21 \mathrm{KJ} / \mathrm{cm}$ & $16-22 \mathrm{KJ} / \mathrm{cm}$ \\
\hline Preheating & $\begin{array}{l}9 \mathrm{t} \cdots \text { none } \\
20 \mathrm{t}, 40 \mathrm{t} \cdots 100^{\circ} \mathrm{C}\end{array}$ & $\begin{array}{l}9 t, 20 t \cdots \text { none } \\
40 \mathrm{t} \cdots 100^{\circ} \mathrm{C}\end{array}$ & none & none & $\begin{array}{r}9 t \cdots \text { none } \\
20 t \cdots 50^{\circ} \mathrm{C}\end{array}$ & $150^{\circ} \mathrm{C}$ \\
\hline Interpass temp. & $100^{\circ} \mathrm{C}$ & $100^{\circ} \mathrm{C}$ & $100^{\circ} \mathrm{C}$ & $100^{\circ} \mathrm{C}$ & $100^{\circ} \mathrm{C}$ & $150^{\circ} \mathrm{C}$ \\
\hline
\end{tabular}

Table 3 Statistically estimated values for angu - ar distortion $\left(v_{0}\right)$ and mismatch $(\delta)$

\begin{tabular}{|c|c|c|c|c|c|}
\hline \multirow{2}{*}{ Material } & \multirow{2}{*}{ Type of joints } & \multicolumn{2}{|c|}{$v_{0}(\mathrm{~mm} / \mathrm{m})$} & \multicolumn{2}{|c|}{$\delta(\mathrm{mm})$} \\
\hline & & mean & $s \cdot d^{1)}$ & mean & $s \cdot d^{1)}$ \\
\hline \multirow{4}{*}{ SM50B } & $\begin{array}{r}\text { Butt welded joint } \\
t=9 \mathrm{~mm} \\
20 \mathrm{~mm} \\
40 \mathrm{~mm}\end{array}$ & $\begin{array}{l}3.68 \\
9.21 \\
6.07\end{array}$ & $\begin{array}{l}1.84 \\
5.83 \\
4.91\end{array}$ & $\begin{array}{l}0.32 \\
0.57 \\
0.47\end{array}$ & $\begin{array}{l}0.19 \\
0.37 \\
0.41\end{array}$ \\
\hline & $\begin{array}{rr}\text { Non-1oad,cruci form } \\
t=9 \mathrm{~mm}, \mathrm{t}_{1}=9 \mathrm{~mm} \\
20 \mathrm{~mm} & 9 \mathrm{~mm} \\
20 \mathrm{~mm} & 20 \mathrm{~mm} \\
40 \mathrm{~mm} & 9 \mathrm{~mm} \\
40 \mathrm{~mm} & 40 \mathrm{~mm}\end{array}$ & $\begin{array}{l}2.16 \\
2.05 \\
2.53 \\
4.22 \\
4.16\end{array}$ & $\begin{array}{l}1.35 \\
1.31 \\
0.80 \\
1.27 \\
2.10\end{array}$ & & 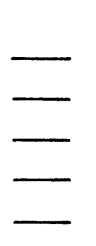 \\
\hline & 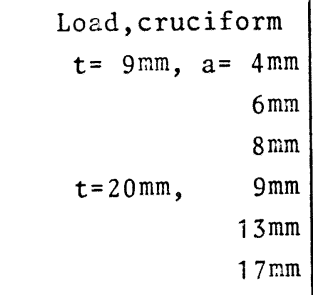 & $\begin{array}{l}8.98 \\
0.97 \\
3.80 \\
3.30 \\
3.30 \\
4.77\end{array}$ & $\begin{array}{l}2.49 \\
0.26 \\
1.31 \\
2.63 \\
2.25 \\
3.45\end{array}$ & $\begin{array}{l}0.94 \\
0.87 \\
0.47 \\
0.37 \\
0.33 \\
0.57\end{array}$ & $\begin{array}{l}0.31 \\
0.52 \\
0.26 \\
0.15 \\
0.28 \\
0.30\end{array}$ \\
\hline & $\begin{array}{r}\text { Load, cruciform }-\mathrm{K} \\
\mathrm{t}=9 \mathrm{~mm} \\
20 \mathrm{~mm}\end{array}$ & $\begin{array}{l}8.74 \\
1.97\end{array}$ & $\begin{array}{l}3.95 \\
1.51\end{array}$ & $\begin{array}{l}0.45 \\
0.17\end{array}$ & $\begin{array}{l}0.28 \\
0.14\end{array}$ \\
\hline SM58Q & $\begin{array}{r}\text { Butt welded joint } \\
t=9 \mathrm{~mm} \\
20 \mathrm{~mm}\end{array}$ & $\begin{array}{l}5.17 \\
3.20\end{array}$ & $\begin{array}{l}2.31 \\
2.13\end{array}$ & $\begin{array}{l}0.35 \\
0.44\end{array}$ & $\begin{array}{l}0.23 \\
0.27\end{array}$ \\
\hline HT 80QT & $\begin{array}{r}\text { Butt welded joint } \\
t=9 \mathrm{~mm} \\
20 \mathrm{~mm}\end{array}$ & $\begin{array}{l}1.79 \\
3.36\end{array}$ & $\begin{array}{l}1.37 \\
1.86\end{array}$ & $\begin{array}{l}0.24 \\
0.35\end{array}$ & $\begin{array}{l}0.20 \\
0.30\end{array}$ \\
\hline
\end{tabular}

1) Standard deviation 


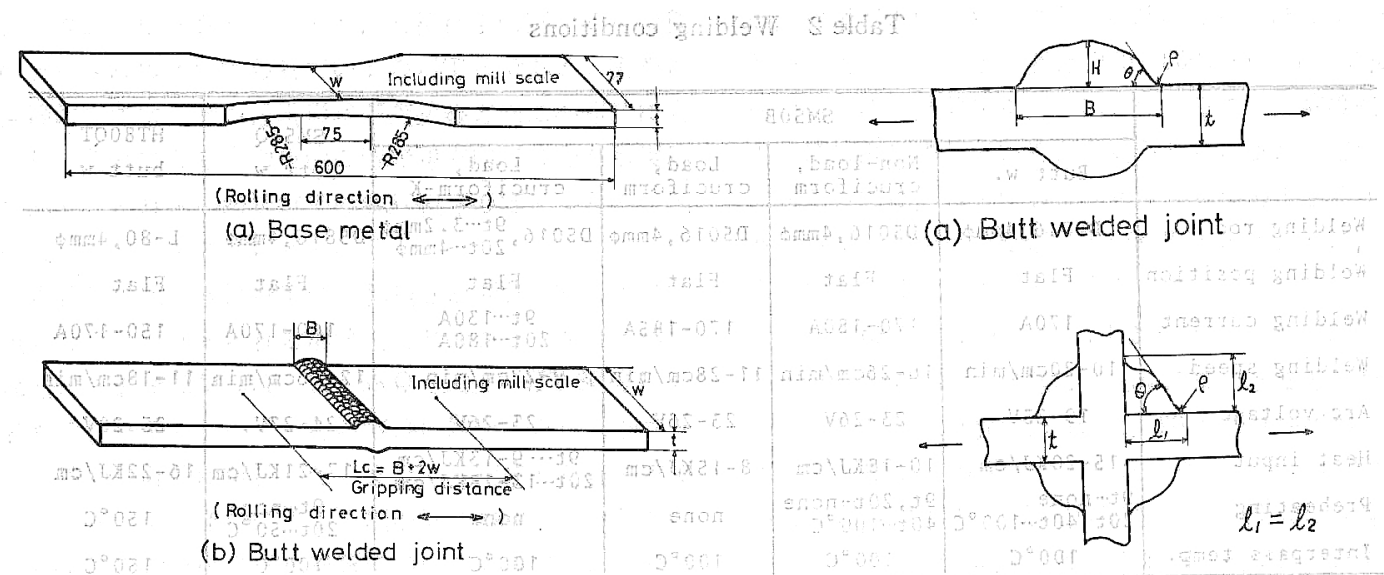

(b) Cruciform fillet welded joint

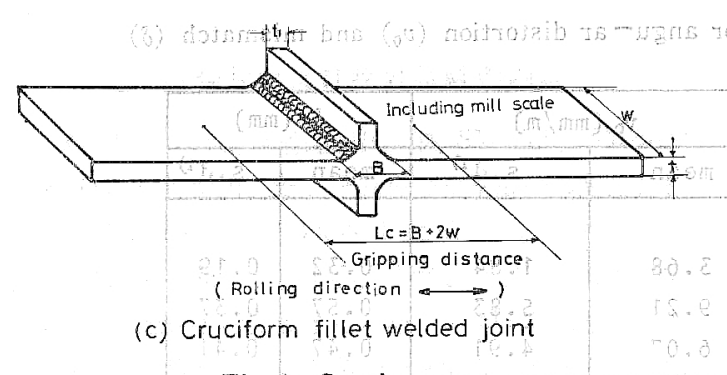

Fig. 1 Specimens

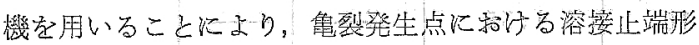
状を Fig. 2 に示すプラメータとついて計測した。

\section{3 試 験 結 果}

\section{1 癌㣗笔裂発生点の観察}

龟裂発生点の溶接部断面形状を調べるたるるる, 疲れ試

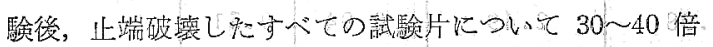

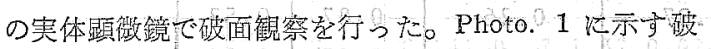

Fig, 2 Shape parameters for reinforcement of welded joints

面例からもわかるように，龟裂の発生点性複数個であっ た ( $\nabla$ 印)。乙れを SM 50 B 突合捕溶接秋手の場合につ いて，疲机破面に拈ける篦裂発生点の数 $n$ 之板幅 $w$ との 比を，負荷応力の関数として Fig. 3 に示した。罒から 龟裂発生点の間隔 $w / n$ は，低応力側で觬荷応力に対し

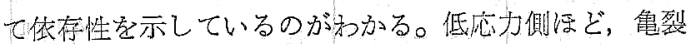

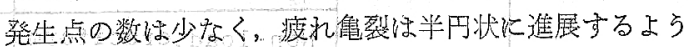
になるの対し，応力が高くなるにつ机て䈉発生点の 数憎加し，板幅の全長に加たって帯状の㫣裂となって

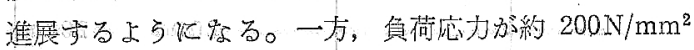

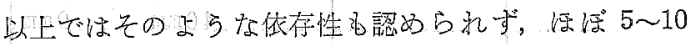
mm 飞一個の書合で艘裂登生点が宓るのがかかる。この ことは，板愊が広くな机ば角裂の発生点の個数成增加す

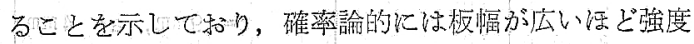
の低下を招くことになるが，本報告で用いた板幅の範国

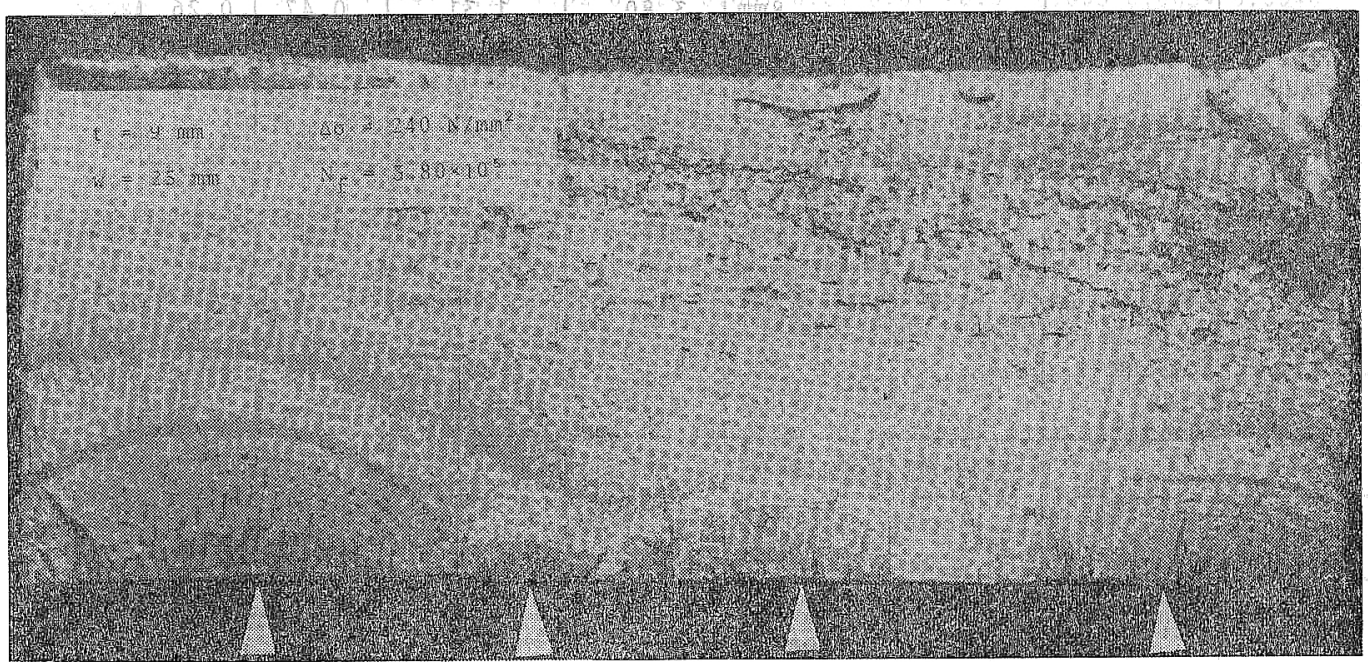

Photo. 1 Fracture surface of SM 50 B butt welded joint $(t=9 \mathrm{~mm})$ 


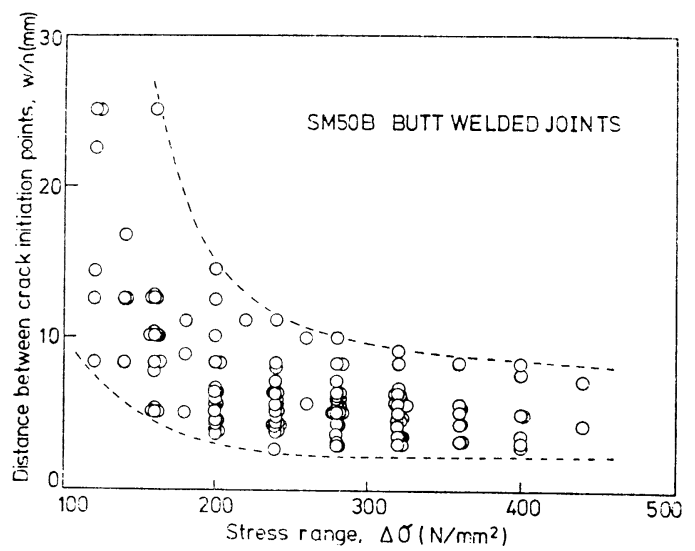

Fig. 3 Relationship between the crack initiation distance and the applied stress range

$(25 \mathrm{~mm} \sim 160 \mathrm{~mm})$ では $5 \%$ の危俟率で疲れ强さに有意

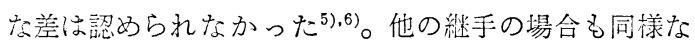
傾向を示しているが，すみ肉継手のように止端部での応 力集中が大きい場合, 応力依存性が認められなくなる負 荷応力は, Fig. 3 の場合よりも低くなった。これは, 溶 㨲止㙐において, 溶接線力向のすべての点が, 局部的に 降伏しれ状態に相当していると考兄られ，溶接継手の亀 裂発生学䘗が，止端部に沶ける局部応力あるいは局部ひ ずみにより支配されていることを示しており，負荷応力 が高くなるほど Topper ら7の提案しているような破壊 条件を満足する点（龟裂発坐点に相当）が增加し, Fig. 3のような傾向を示したものと考えられる。従って, 急

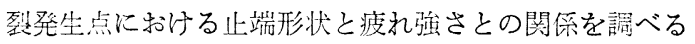
腙も上記の点が問題となるが，本報告では，その影響が ほぼ無いと考觉られる $5 \times 10^{5}$ 回の寿命における時間強 さを主として用いた。

\section{2 疲れ強さの変動}

SM 50 B 材の各継手群の 95\% 信頼区間を, 例として 板厚 $20 \mathrm{~mm}$ の場合について Fig. 4 に示した。母材, 突 含せ, リブ十字, 十字継手の順に疲れ強さが低下してい るのがうかか。十字すみ肉継手の場合, 寸み肉の大きさ により止端破壊するものと, ルート破填するものがあ り，このうち止端破壞したものについてのみ以下の検討 に用いた。その他の突合せ, リブ十字, 十字 $\mathrm{K}$ 開先継手 はすべて止端破壊であった。したがって, 溶接止端形状 と疲れ強さとの椧馀に用いたグループの数は18である。

一条件に护る同一応力レベルでの実験点が少ないた め，全グループについてその破断寿命分布を調べること はできなかったが，SM 50 B 突合せ継手では，疲労限よ りも高い応力筙囲で, 板厚によらず寿命はほぼ対数正規 分布とみなすことができ，そのときの変動係数は 0.13 〜 0.25 で㐫り，低応力侧の方が変動係数は大きくなる

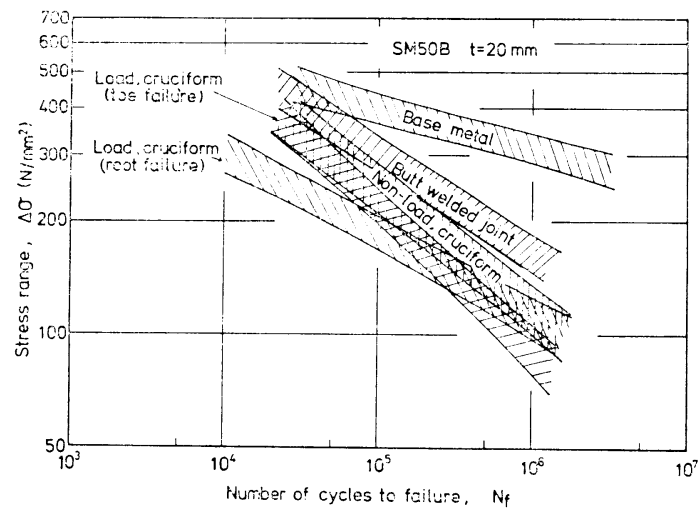

Fig. $495 \%$ confidence intervals for SM $50 \mathrm{~B}$ welded joints $(t=20 \mathrm{~mm})$

傾向にあった。西島ら 8$)$ も, 繰返し数が $10^{6}$ 回未満程度 の䈇国では，寿命はほぼ対数正規分布とみなし得るとし ており，本報告の結果と一致している。本報告では，そ の範囲内の実験点を最小自乘法を用いて $\log -\log$ の一次 回归を行って平均值 $S-N$ を求め, その回帰パラメータ をTable 4 に亦した。それからの実験点の相対強度偏 差を統計量として扱い, Fig. 5 に SM 50 B, 板厚 $9 \mathrm{~mm}$ の場合について, 正規確率紙にプロットしたが, 他の継 手の場合も同様にほぼ正規分布とみなすことができた。 ここで，確率梹のプロットには（1）武を用いた。

$$
P=i /(m+1)
$$

mはデータ総数, $i$ は澒位数である。これらのプロット 点を直線回帰することにより変動係数を求めてみると, 他の板厚の場合も含めて SM 50 B では，母材が $3.7 \%$ ６.1\%，突合せ継手で $6.2 \%$ ．7\%，すみ肉継手で 6.7\%〜9.4\%となっていた。母材よりも溶接継手の方が $50 \%$ 程度変動係数が大きくなっており，この傾向は SM $58 \mathrm{Q}, \mathrm{HT} 80 \mathrm{QT}$ 材についてもほぼ同様であった。この ように，溶接継手の疲れ強さは継手の種類によらず，ほ ぼ同程度の変動係数を示し, これは後述するように, 溶 接止端の応力集中係数の変動係数が継手の種類によら ず, ほぼ50\% 前後であることと良く対応しているもの と考えられる。

\section{3 溶接継手の止端形状}

Fig. 2 に示す形状パラメータについて, 疲れ試虽前に 型取りしたシリコンゴムを用いて，亀裂発生点に括ける 溶接止端部の断面形状を謂べた。それらを統計量として 確率紙上にプロットし，直線回㷌することにより，その 分布の形, 平均值, 標準偏差の推定值を Table 5 (a) 5 (f) に示した。すみ肉溶接継手の脚長は，N K 鋼船哯 則 ${ }^{9)}$ に基づき，各板厚ごとにそのサイズを定めたため， 表中のように板厚ごとに異なっている。また，試験片の 個々の測定点における溶接止端部の形状パラメータか 


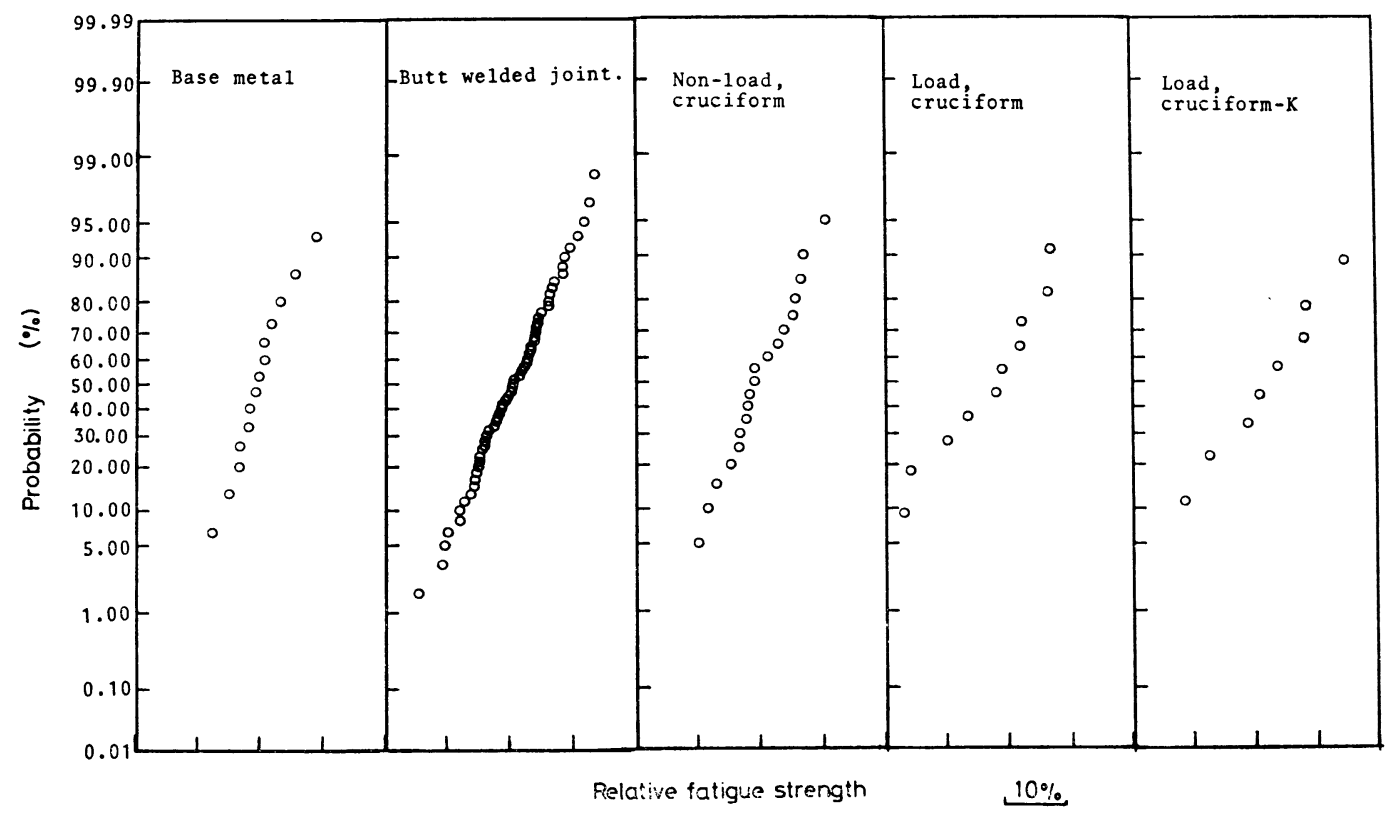

Fig. 5 Distributions for the relative fatigue strength deviation

Table 4 Regression parameters for $S-N$ relationship

\begin{tabular}{|c|c|c|c|c|c|c|}
\hline Reg. parameter & \multicolumn{3}{|c|}{ A } & \multicolumn{3}{|c|}{ B } \\
\hline $\begin{array}{c}\text { Type of } \\
\text { joints }\end{array}$ & 9 & 20 & 40 & 9 & 20 & 40 \\
\hline \multicolumn{7}{|l|}{ SM50B } \\
\hline base metal & 0.1155 & 0.1057 & 0.0789 & 3.2086 & 3.1359 & 2.9856 \\
\hline $\begin{array}{l}\text { butt welded joints } \\
\text { non-load,cruciform }\end{array}$ & 0.2200 & 0.2631 & 0.2458 & 3.6282 & 3.7962 & 3.6866 \\
\hline$t_{1}=9 \mathrm{~mm}$ & 0.2700 & 0.2880 & 0.3318 & 3.8307 & 3.8386 & 4.0410 \\
\hline $20 \mathrm{~mm}$ & - & 0.3159 & $\longrightarrow$ & & 3.9338 & \\
\hline $40 \mathrm{~mm}$ & - & - & 0.3134 & - & & 3.9271 \\
\hline \multicolumn{7}{|l|}{ load,cruciform } \\
\hline $2 \mathrm{a} / \mathrm{t}=0.85$ & 0.2477 & 0.2117 & - & 3.4962 & 3.3262 & \\
\hline 1.34 & 0.3451 & 0.2954 & & 4.0702 & 3.8831 & \\
\hline 1.70 & 0.3362 & 0.3656 & & 3.9852 & 4.1682 & \\
\hline load,cruciform-K & 0.3419 & 0.3366 & & 4.1024 & 4.0791 & \\
\hline \multicolumn{7}{|l|}{ SM58Q } \\
\hline base metal & 0.1633 & 0.1656 & 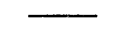 & 3.5531 & 3.5599 & \\
\hline butt welded joints & 0.1693 & 0.2744 & & 3.3571 & 3.8971 & \\
\hline \multicolumn{7}{|l|}{ HT 80QT } \\
\hline base metal & 0.1335 & 0.1608 & & 3.4045 & 3.5631 & \\
\hline butt welded joints & 0.2459 & 0.2709 & 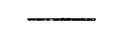 & 3.7685 & 3.8455 & - \\
\hline
\end{tabular}


Table 5 Statistically estimated values for shape parameter of reinforcement

(a) SM50B butt welded joints.

\begin{tabular}{|c|c|c|c|c|c|c|c|c|c|}
\hline \multicolumn{2}{|c|}{ Parameter } & \multicolumn{2}{|c|}{$\rho$} & \multicolumn{2}{c|}{$\theta$} & \multicolumn{2}{c|}{ H } & \multicolumn{2}{c|}{ B } \\
\hline \multicolumn{2}{|c|}{ Distribution } & \multicolumn{2}{|c|}{ log-normal } & \multicolumn{2}{c|}{1 log-normal } & \multicolumn{2}{c|}{ norma1 } & \multicolumn{2}{c|}{ norma1 } \\
\cline { 2 - 9 } & mean & s.d & mean & s.d & mean & s.d & mean & s.d \\
\hline \multirow{4}{*}{$t$} & 9 & 0.478 & 0.425 & 34.0 & 5.2 & 2.36 & 0.37 & 10.55 & 0.80 \\
& 20 & 0.588 & 0.394 & 41.1 & 5.7 & 3.00 & 0.51 & 18.28 & 1.56 \\
& 40 & 0.556 & 0.402 & 34.4 & 8.4 & 3.58 & 0.47 & 30.36 & 3.34 \\
\hline
\end{tabular}

(b) SM50B non-load carrying cruciform fillet welded joints.

\begin{tabular}{|c|c|c|c|c|c|c|c|c|c|}
\hline & \multicolumn{3}{|c|}{ Parameter } & \multicolumn{2}{|c|}{$\rho$} & \multicolumn{2}{|c|}{$\theta$} & \multicolumn{2}{|c|}{1} \\
\hline & \multicolumn{3}{|c|}{ Distribution } & \multicolumn{2}{|c|}{ log-normal } & \multicolumn{2}{|c|}{ norma 1} & \multicolumn{2}{|c|}{ norma 1} \\
\hline & & & & mean & s.d & mean & s.d & mean & s.d \\
\hline \multirow[t]{5}{*}{$t$} & 9 & $t_{1}$ & 9 & 0.359 & 0.198 & 39.2 & 16.2 & 6.50 & 0.55 \\
\hline & 20 & & 9 & 0.403 & 0.252 & 47.6 & 12.0 & 9.98 & 0.69 \\
\hline & \multirow{3}{*}{40} & & 20 & 0.329 & 0.174 & 50.9 & 13.9 & 10.39 & 0.73 \\
\hline & & & 9 & 0.425 & 0.221 & 36.7 & 8.5 & 12.61 & 0.65 \\
\hline & & & 40 & 0.392 & 0.303 & 37.4 & 11.9 & 11.95 & 0.73 \\
\hline
\end{tabular}

(c) SM50B load-carrying cruciform fillet welded joints.

\begin{tabular}{|c|c|c|c|c|c|c|c|c|c|}
\hline & \multicolumn{3}{|c|}{ Parameter } & \multicolumn{2}{|c|}{$\rho$} & \multicolumn{2}{|c|}{$\theta$} & \multicolumn{2}{|c|}{1} \\
\hline \multicolumn{4}{|c|}{ Distribution } & \multicolumn{2}{|c|}{ log-normal } & \multicolumn{2}{|c|}{ norma 1} & \multicolumn{2}{|c|}{ normal } \\
\hline & & & & mean & s.d & mean & s.d & mean & s.d \\
\hline \multirow[t]{6}{*}{$t$} & 9 & $a^{i)}$ & 4 & 0.382 & 0.126 & 42.9 & 11.0 & 6.30 & 0.39 \\
\hline & & & 6 & 0.334 & 0.153 & 53.9 & 12.7 & 7.50 & 0.85 \\
\hline & & & 3 & 0.362 & 0.271 & 43.7 & 12.2 & 10.83 & 0.69 \\
\hline & 20 & & 9 & 0.321 & 0.120 & 45.8 & 13.8 & 12.79 & 0.78 \\
\hline & & & 13 & 0.337 & 0.195 & 51.6 & 15.4 & 19.06 & 1.43 \\
\hline & & & 17 & 0.453 & 0.291 & 50.9 & 16.8 & 24.09 & 1.15 \\
\hline
\end{tabular}

1) Objective value. 
Fig. 5-2

(d) SM50B load-carrying cruciform K-fillet welded joints.

\begin{tabular}{|c|c|c|c|c|c|c|c|}
\hline \multicolumn{2}{|c|}{ Parameter } & \multicolumn{2}{|c|}{$\rho$} & \multicolumn{2}{c|}{$\theta$} & \multicolumn{2}{c|}{1} \\
\hline \multirow{2}{*}{ Distribution } & \multicolumn{2}{|c|}{ log-norma1 } & \multicolumn{2}{c|}{ norma1 } & \multicolumn{2}{c|}{ norma 1 } \\
\cline { 2 - 8 } & mean & s.d & mean & s.d & mean & s.d \\
\hline \multirow{2}{*}{$t$} & 9 & 0.408 & 0.223 & 46.5 & 9.3 & 9.07 & 0.96 \\
& 20 & 0.426 & 0.336 & 40.0 & 8.4 & 15.7 & 0.99 \\
\hline
\end{tabular}

(e) SM58Q butt welded joints.

\begin{tabular}{|c|c|c|c|c|c|c|c|}
\hline \multicolumn{2}{|c|}{ Parameter } & \multicolumn{2}{|c|}{$\rho$} & \multicolumn{2}{c|}{$\theta$} & \multicolumn{2}{c|}{$H$} \\
\hline \multirow{2}{*}{ Distribution } & \multicolumn{2}{|c|}{ 1og-norma 1 } & \multicolumn{2}{c|}{ norma1 } & \multicolumn{2}{c|}{ norma 1 } \\
\cline { 2 - 8 } & mean & s.d & mean & s.d & mean & s.d \\
\hline \multirow{2}{*}{$t$} & 9 & 0.591 & 0.417 & 32.5 & 10.4 & 2.29 & 0.52 \\
& 20 & 0.632 & 0.436 & 32.2 & 10.2 & 2.83 & 0.41 \\
\hline
\end{tabular}

(f) HT80QT butt welded joints.

\begin{tabular}{|c|c|c|c|c|c|c|c|}
\hline \multicolumn{2}{|c|}{ Parameter } & \multicolumn{2}{|c|}{$\rho$} & \multicolumn{2}{c|}{$\theta$} & \multicolumn{2}{c|}{$H$} \\
\hline \multirow{2}{*}{ Distribution } & \multicolumn{2}{|c|}{1 log-norma1 } & \multicolumn{2}{c|}{ norma1 } & \multicolumn{2}{c|}{ norma 1 } \\
\cline { 2 - 8 } & mean & s.d & mean & s.d & mean & s.d \\
\hline \multirow{2}{*}{$t$} & 9 & 0.739 & 0.473 & 23.8 & 10.8 & 1.66 & 0.33 \\
& 20 & 0.679 & 0.407 & 31.0 & 17.5 & 2.89 & 0.46 \\
\hline
\end{tabular}

ら，(2）式10)を用いて，俺裂発生点に括ける止端部の 応力集中係数 $K_{t}$ を求め, それらの統計的諸抄質を求め た。

$$
\begin{gathered}
K_{t}=f(\theta)\left(\alpha_{0}-1\right) \\
\alpha_{0}=1+\left[1 /\left(2.8 \Delta_{1}-2\right) \cdot H / \rho\right]^{0.65} \\
f(\theta)=\left[1-\exp \left(-0.90 \pi \theta \sqrt{\Delta_{2}} / 180\right)\right] / \\
\times\left[1-\exp \left(-0.45 \pi \sqrt{\Delta_{2}}\right)\right] \\
\Delta_{1}=(2 H+t) / t, \quad \Delta_{2}=(2 H+t) / 2 H
\end{gathered}
$$

$K_{t}$ については, Fig. 6 に示すように, $K_{t}-1$ として 対数正規確率紙にプロットすると良い直線関係を示すこ とから ${ }^{5), 6)}$, 便宜的に対数正規分布として取り扱い, 前 述の試験ごとに $K_{t}-1$ の平均値と標準偏差の推定値を 求め, それらを Table 6 に示した。これらの変動保数
は, 材種, 継手の種類によらず, ほぼ 0.4〜0.6 の間に あった。

\section{4 考察}

\section{1 疲れ強さに及ぼす溶接止端形状の影響}

止端形状の影響を（2）式から求めた急裂発生点にお ける応力集中係数 $K_{t}$ で代表させた。継手の疲れ強さ と $K_{t}$ の関係は Fig. 7 のように模式的に表わすことが できる。図中の○印は前述のように, 材種, 継手の種 類, 板厚, のど厚, リブ厚等で分類した各グループ（た とえば, SM 50 B 突合せ溶接継手, 板厚 $9 \mathrm{~mm}$ ) の平均 值，だ円は各グループ内のデータの散布状沉を模式的に 示したものである。本節では，それらグループ間の疲れ 
Table 6 Statistically estimated values for $K_{t}-1$

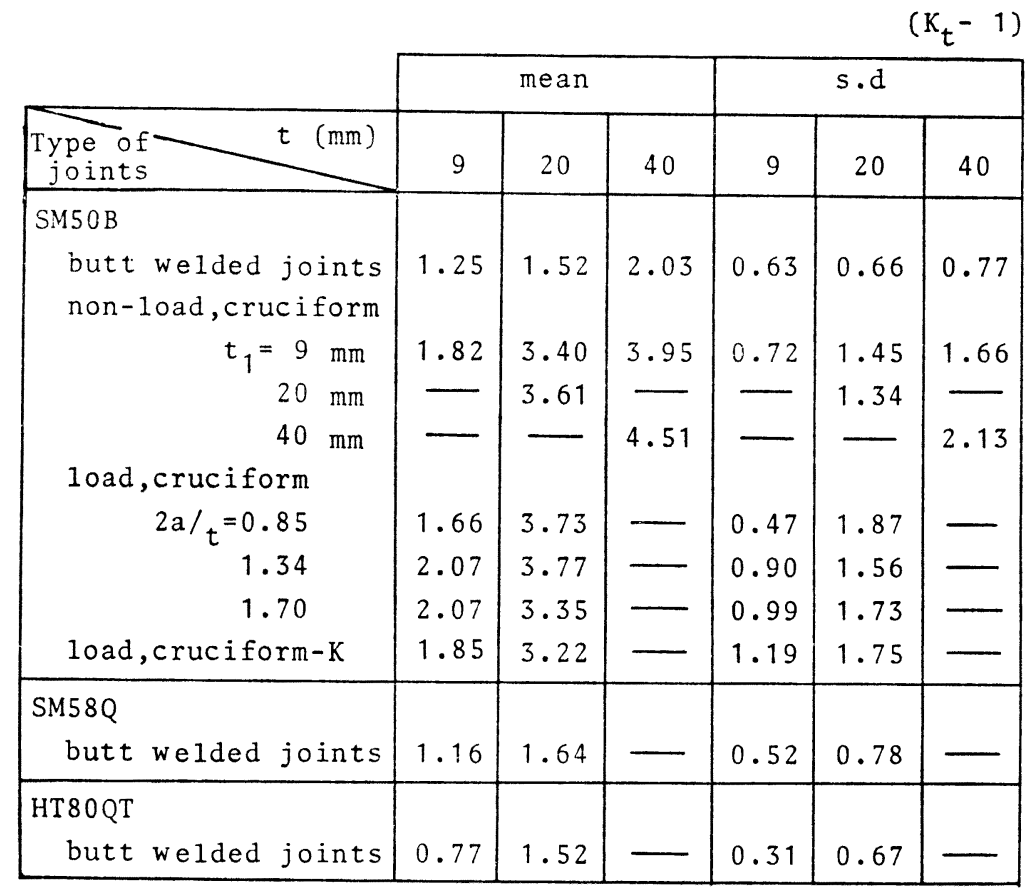

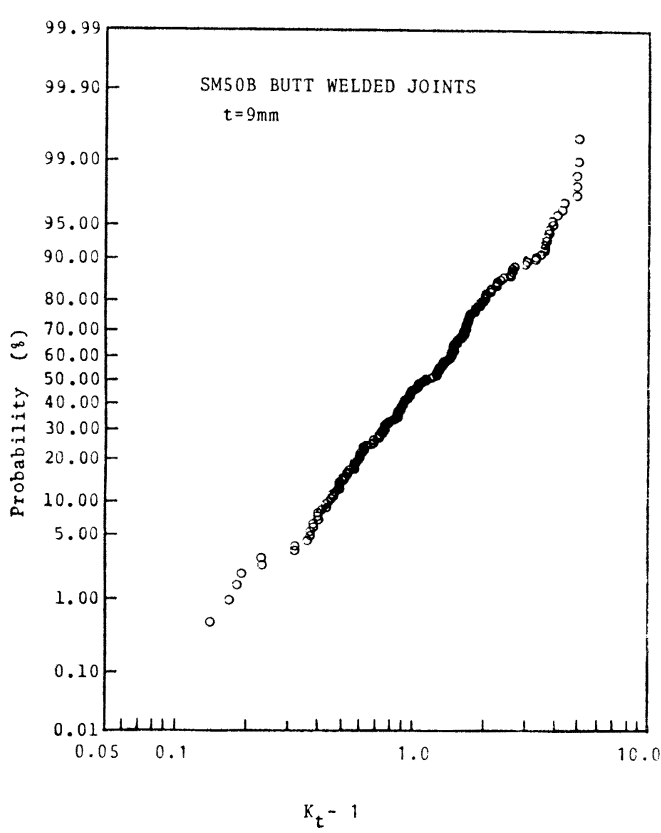

Fig. 6 Distributions for the stress concentration factor $\left(K_{t}-1\right)$ at the toe of the weld

强さの変動と,グループ内の疲れ強さの变動とをそれぞ れ，溶接止端形状との関連から検討した。

(a) グループ間の疲れ強さの変動

各グループごとに，それぞれ統計的に推定した時間強

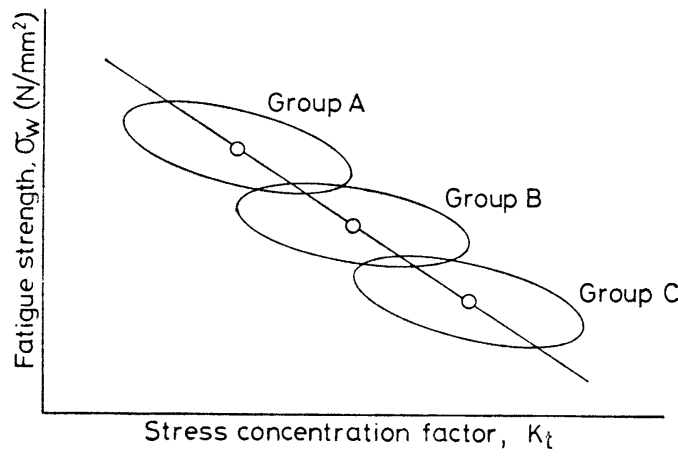

Fig. 7 Illustration for the correlation between the fatigue strength and the stress concentration factor

さの平均值を用いて, グループ間の疲れ強さの変動を調 ベた。Fig. 8 に $5 \times 10^{5}$ 回の時間強さと $K_{t}$ との関係を 示した。継手の種類ごとに図中に示すような記号を用 い，以後の図でもこの記号を用いることにする。

この場合の相関係数は 0.81 であり，グループ間の疲 れ強さの変動の $2 / 3$ は溶接止端部の応力集中に起因して いることがわかる。また，図から十字および十字K開先 すみ肉継手の疲れ強さが，他の継手に比較して低下して いることがわかる。この原因として, 目違い, 角変形量 の各グループ間の变動が考えられ，各グループごとに Table 3 に示した平均值を用い, 梁理論に基づき剪断力 を無視して公称曲げ応力 $\sigma_{w b}$ を求め, Fig. 8 の時間強さ 


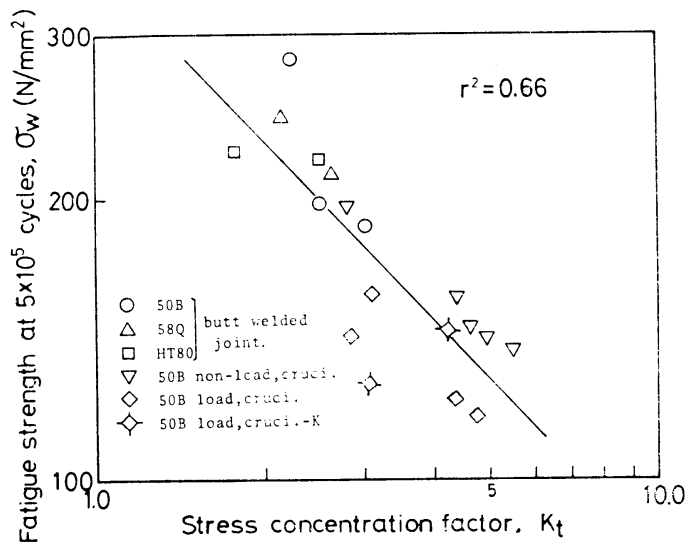

Fig. 8 Relationship between the mean fatigue strength at $5 \times 10^{5}$ cycles and mean stress concentration factor for each group

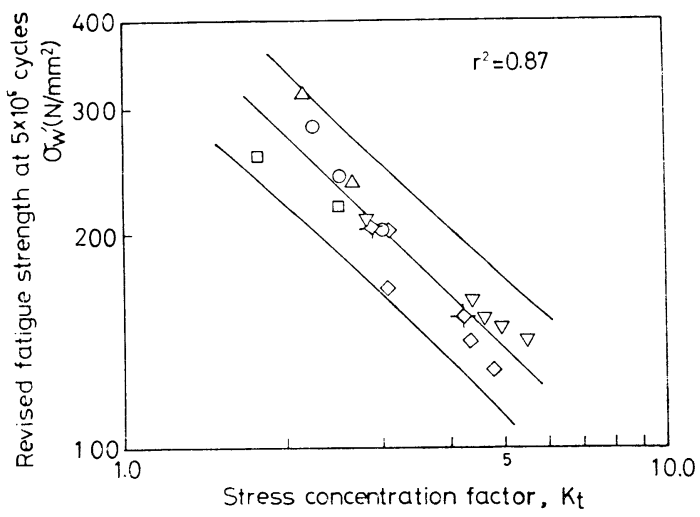

Fig. 9 Revised relationship for Fig. 8

の平均値を（3）式のように補正して Fig. 9 に示した。

$$
\begin{aligned}
\sigma_{w}^{\prime} & =\sigma_{w}+\sigma_{w b} \\
\sigma_{w b} / \sigma_{w} & =3\left(L v_{0} / 2+\delta\right) / t
\end{aligned}
$$

本報告の場合，グループ間の疲れ強さの変動は，止端 部の忘力集中と, 止端部における角変形, 目違いによる 曲げ応力との相乗効果により $87 \%$ まで説明され，材種 による多少の変動を無視すれば，（4）式のように表わす ことができる。

$$
\sigma_{w}^{\prime} \cdot K_{t}^{0.75}=462
$$

(b) グループ内の疲れ強さの変動

Fig. 10 に, グループ内の疲れ強さの変動の例として, SM 50 B 突合せ溶接継手, 板厚 $9 \mathrm{~mm}$ の場合を示した。 縦軸は平均值 $S-N$ 曲線からの応力の偏差の相対值, 横 軸は個々の試験片ごとの亀裂発生点における $K_{t}$ で岕 る。亀裂発生点は前述のように一般に複数個であり, そ の場合, 横軸の $K_{t}$ の值は各試験片ごとの平均值の推定 值を用いた。他のグループについても Fig. 10 と同様な 䫗向が得られた。Fig. 10 の場合，相関係数は 0.53 とな

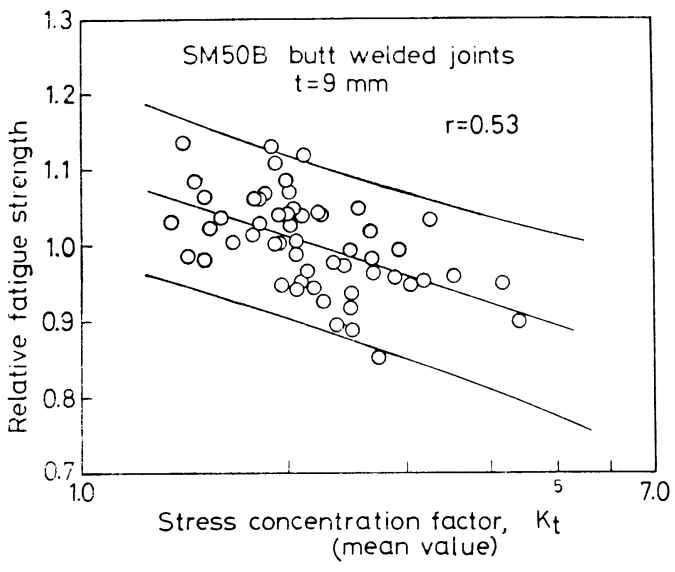

Fig. 10 Correlation between the relative fatigue strength and $K_{t}$ for SM 50 B butt welded joints $(t=9 \mathrm{~mm})$

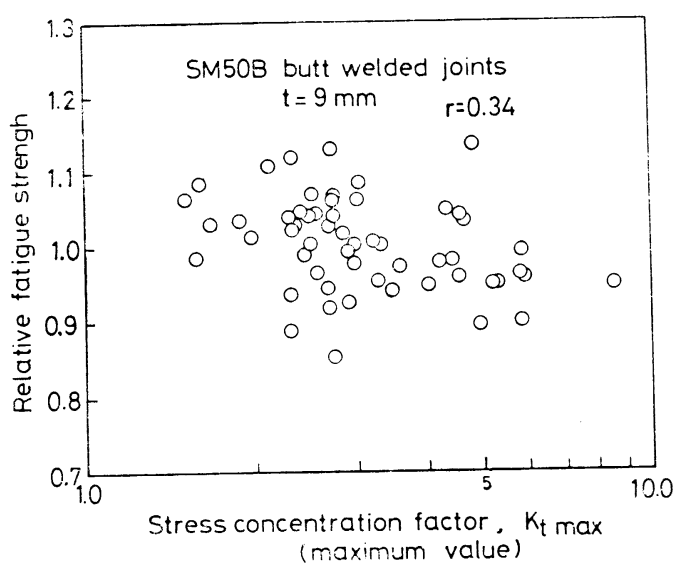

Fig. 11 Correlation between the relative fatigue strength and the maximum stress concentration factor for each specimen

り,グループ内の疲れ強さの变動の $28 \%$ しか $K_{t}$ で説 明できない。Fig. 11 は横軸に各試験片ごとの $K_{t}$ の最 大值を用いたもので, 相関係数は 0.34 となり, 必ずし も $K_{t}$ の大きい点の止端形状が継手の疲れ強さを支配し ているのではないことがわかる。一方，Fig. 10 の実験 点は, 試験片幅, 試験速度等の試験条件が種々にわたっ ており, Fig. 12 に板幅 $25 \mathrm{~mm}$ の試験片のみの緢果を 示した。この場合，相関係数は 0.63 で，Fig. 10 の場合 よりも寄与率は高くなり，疲れ強さのほぼ $40 \%$ が $K_{t}$ の変動で説明される。Fig. 13 は, SM 50 B 突合せ, お よびリブ十字継手について, 各板厚, 板幅ごとに疲れ強 さの变動に対する $K_{t}$ の奇与率を求め, 板幅の関数とし

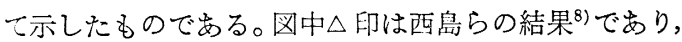
（）付きのものは，相関係数が $5 \%$ の危険率で有意にな らなかったものである。これから，板幅が大きくなるに 


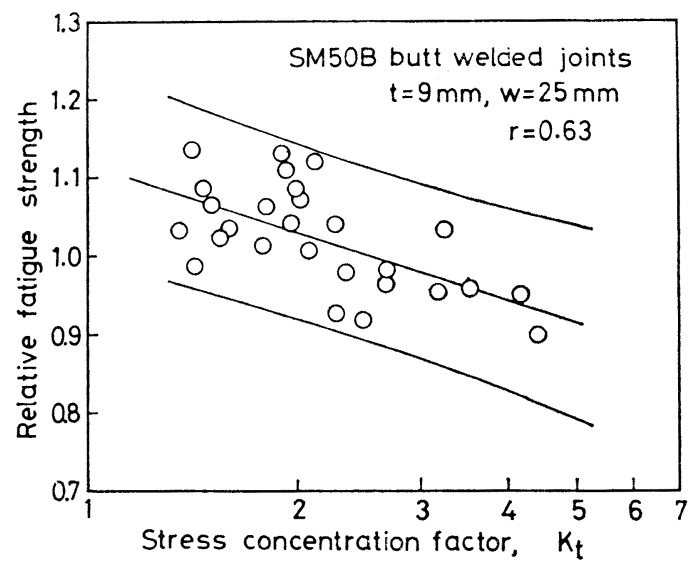

Fig. 12 Correlation between the relative fatigue strength and $K_{t}$ for SM 50 B butt welded joints $(t=9 \mathrm{~mm}, w=25 \mathrm{~mm})$

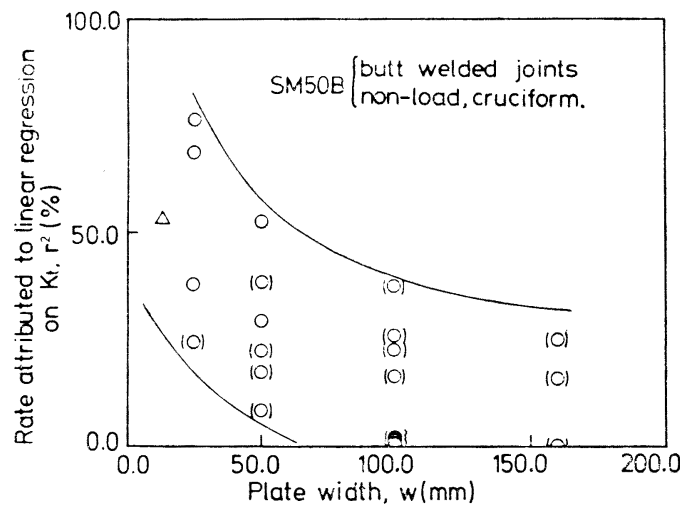

Fig. 13 Relationship between the rate attributed to linear regression on $K_{t}$ and the plate width

従って相関はなくなり，K，の等与は低くなる傾向にあ る。これは, 止端形状の测定点数, 言い換えると, 亀裂 発生点数の問題であり, 亀裂発生点数が増加するに位 い, 一試験片内の見かけの $K_{t}$ の変動係数が大きくな り, 本報告で用いたような平均值で, 個々の試験片の止 端形状を必ずしも代表し得なくなっていることを示して いるものと考えられ，3.1 節に打ける亀裂発生点数の負 荷応力に对する依存性とも関連してくる。したがって,

Fig. 10 で表わされる疲れ強さの变動の残りの分は, 上 述のような試験片を代表する $K_{t}$ のとり方の問題, 試験 片ごとの目違い, 角変形による変動, 疲れ試験条件によ る変動, 急裂発生点に打ける材質的不均一性に基づく变 動などにより説明されると考えられる。

以上のように, 疲れ強さの変動をグループ間の変動と グループ内の变動とに分けて検討した。その結果, グル ープ内の变動, 言い換えると個々の試験片の疲れ強さの
変動に対する $K_{t}$ の夻与は意外に低いことがふかった。 これは前述の変動要因の中でも, 訊験片を代裁する $K_{t}$ の求め方の問題が最も大きいと考兄られ, 定性的には次 のような理由が考学られる。止端部に括ける镚小な疲れ 亀裂の発生は止端部の点の $K_{t}$ に依存するとしても, 溶 接継手の場合, それは全疲れ寿命のごく一部を占めるだ けで，寿命の大半はそれ以降の微小な初期龟裂の合体， あるいは再合体を含さ，疲れ亀裂の伝ぱにより占められ ており，実用上の亀裂発生注亀裂の伝ぱ過程に岕ると考

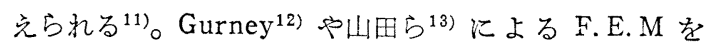
用いた解析により, 溶接継手の止端形状が亀裂の伝ぱに 及汸影響が調べられているが，それによると，亀裂深 さが板厚の $0.2 \sim 0.3$ 程度までは止端形状による応力集 中の影響があるとしており，余盛の岕る溶接継手の亀裂 伝ぱ過程に及ぼす止端形状の影響が大きいのがわかる。 一力, 止端部で発生した亀裂は, Photo. 1 のように表 面亀裂として伝ぱし，亀裂の成長に伴って板蝠方向にも その大きさを搪げ，伝ぱに影響を及ぼす止端形状も領域 を桩大して，その領域の平均的な形状が疲れ強さに影響 を及济すようになってくるものと考えられる。そのた め, 止端部における $K_{t}$ の溶接線方向の分布によって, また，その時点の亀裂の大きさにより，とるべき領域の 大きさが異なり, 寄与する $K_{t}$ の值が変化することが考 えられる。したがって, 複数個の亀裂発生点がある試験 片ごとの解析の際は, 亀裂発生点の $K_{t}$ の平均值だけで は十分な相関を得ることはむずかしく，結果として，グ ループ内の変動に対する $K_{t}$ の寄与が低くなったものと 考えられる。このように，個々の試験片ごとに $K_{t}$ と疲 れ強さを対応させるのは, 現時点ではまだ問題があると 考光られるが，それらを一括して取り扱い，グループと しての平均的な性質で検討したグループ間の疲れ強さの 変動は (4) 式で表わされ, $K_{t}$ 之, 目違い, 角変形に よる曲げ応力との相乗効果で注注説明される。

\section{2 溶接止端形状に及ぼす溶接条件の影響}

前節において, 材種, 継手の種類, 寸法等により分類 したグループ間の疲れ強さの変動が, 余盛止端形状によ る灾力集中と, 目違い, 角变形に伴う朋げ応力との相乘 効果で注湆説明されることがわかった。それらは溶挼施 工条件によりその値を变えることが予想され，本節で は, 溶接止端形状と溶接条件の影響をグループ間の変動 としてとらえ, それら各グループの平均值を用いて, 溶 接条件の影響を検討した。Fig. 2 に示す余盛形汱を表わ す形状パラメータは，溶接条件によりその值が变化し，

Fig. 14 のような入熱量 $Q$ との相関が得られた。ここで, $Q$ の值は止端部に括ける余盛最終層の平均入熱量として 求めた。一方, 前節で疲れ強さと対応する余盛形状を代 表するパラメータとして $K_{t}$ を用いたが， $K_{t}$ は $\rho / t, \theta$, 

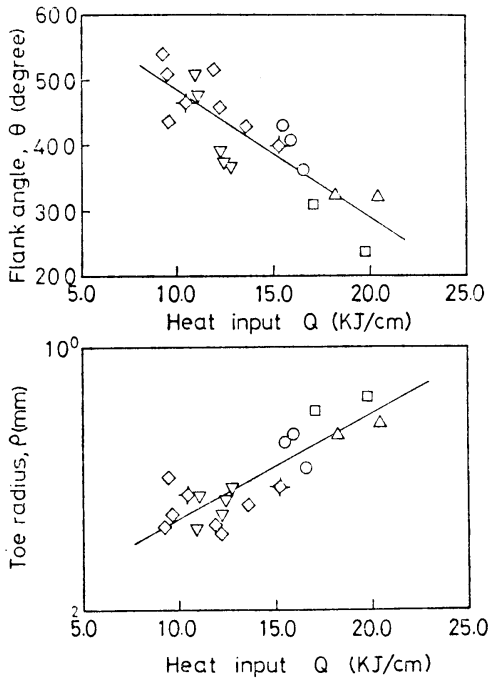

Fig. 14 Correlation between the shape parameters of reinforcement and the heat input

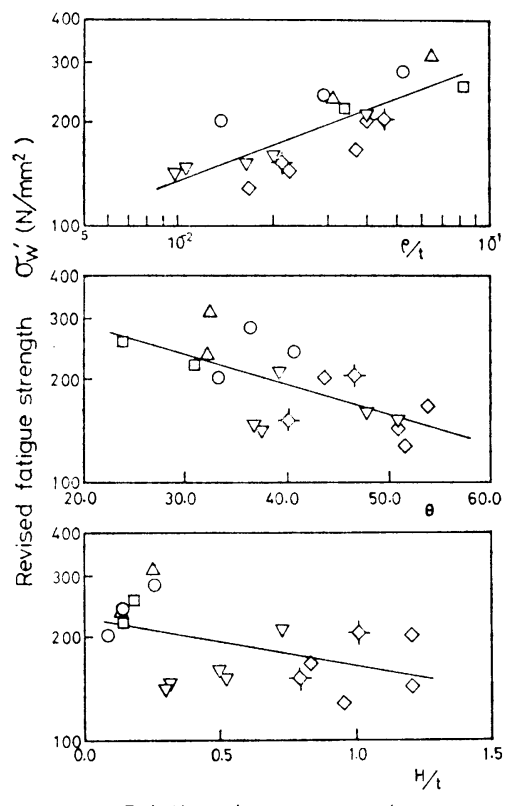

Relative shape paramete-

Fig. 15 Correlation between the revised fatigue strength and the relative shape parameter

$H / t$ (す又肉継手の場合は $l / t)$ に依存し，それらのパラ メータは疲れ強さとの間に Fig. 15 に示すような関倸が ある。これから，疲れ强さを支配するパラメータとして は $\rho / t$ と $\theta$ の影響が大きく，このことは，溶接止端形 状を滑らかにすることにより度れ強さを改善できること からも明らかである ${ }^{3)}$ 。市。一方，Fig. 14 からもかかるよ
らに、これらの形状パラメータは溶接条件の影響を受 け，止端部に怙ける表面張力と重力のバランスからその 形忛が定まり，溶接の際の冷却過程や溶融金属の物理的 性質により変化するものと考えられる。これらは，溶接 金属が凝固を開始した直後の，ごく短時間の高温側の状 態で支配されると考えられるが，本報告では便宜上，溶 接部の強さや切欠じん性などに関連する冷却過程として よく用いられる，溶接ボンド部における $800^{\circ} \mathrm{C}$ から 500 ${ }^{\circ} \mathrm{C}$ までの冷却時間 $S_{8 / 5}$ を稲垣ら ${ }^{14)}$ による (5) 式から 求め, これをパラメータとして用いた。

$$
\begin{aligned}
S_{8 / 5}= & K \cdot(1000 Q)^{n} / B\left(600-T_{0}\right)^{2} \\
& \times\left\{1+\frac{2}{\pi} \tan ^{-1}\left(\frac{t-t_{0}}{\alpha}\right)\right\}(\mathrm{sec})
\end{aligned}
$$

本報告のような被覆アーク溶接の場合, $n=1.5, K=$ 1. $35, t_{0}=1.46, \alpha=6.0, \beta=1.0$ (平板), 2.0 (すみ肉) の值を与えており，これから各継手ごとに冷却時間の平 均値を求め，疲れ強さに影響を及ぼす形状パラメータ $\rho / t, \theta$ との関係を Fig. 16 に示した。たたし（5）式の

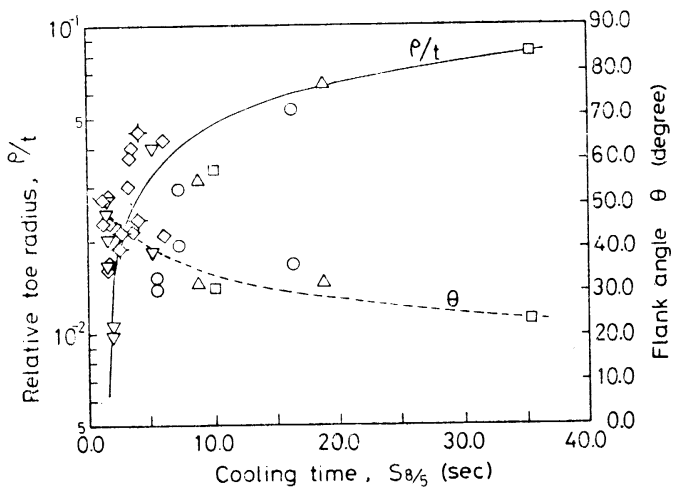

Fig. 16 Relationship between the relative shape parameters and the cooling time due to Eq. (5)

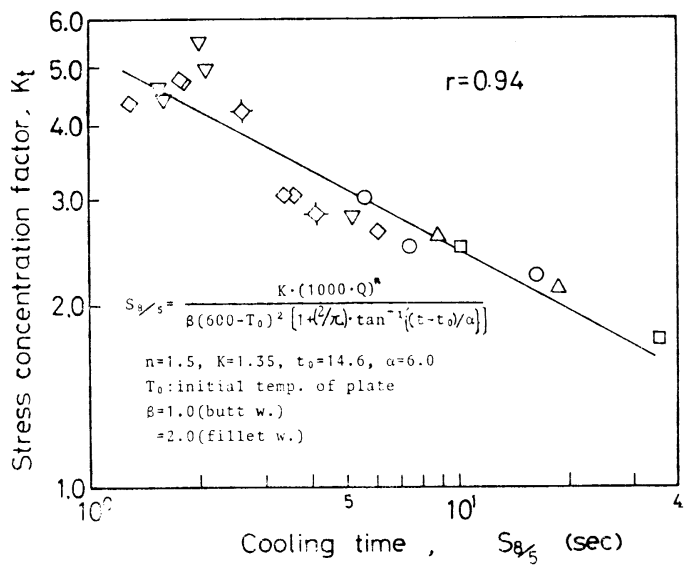

Fig. 17 Correlation between $K_{t}$ and the cooling time due to Eq. (5) 
入熱量 $Q$ としては，最終層の平均入熱量で代表させ， $T_{0}$ は板の初温とし，予熱がない場合は $20^{\circ} \mathrm{C}$ とした。これ から， $S_{8 / 5}$ が $5 \sim 10 \mathrm{sec}$ 以下では $\rho / t$ が急漖に小さくな 门，冷却時間に強く依存していることがわかる。一方， $\theta$ は冷却時間が大きくなるに従い, いくらか小さくなる 項向にあるが， $\rho / l$ ほど领却時間に依存していない。こ のような形快パラメータの泠却時間に対する统有性は, 結果として Fig. 17 に示すように灾力集中係数 $K$ の泠 却時間に対する依存性として現われ，後述するように度 れ強さにも影響を与える。

\section{3 疲れ強さに及ぼす溶接条件の影響}

前節で溶接止端形状パラメータに及ぽす溶接条件の影 揞を検討した。疲れ強さに対しては，さらに溶接施工に 伴う組織变化の影響として，切欠感受性の变化が学えら れる。Fig. 18 には， $5 \times 10^{5}$ 回の繰返し数に尔汁る目違 い，角变形の影留を補正した溶接継手の時間強さの平均 值と, 平滑母材の時間強さの平均值との比を $K_{f}^{\prime}$ とて 求め， $K_{t}$ との関係を示した。HT 80 QT 枋が扰の材種 に比較して，いく分切欠感受性が高いように見えるが，

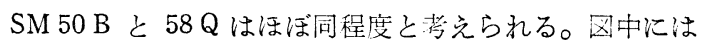
SM $50 \mathrm{~A}$ 目村切欠材の結果 ${ }^{15)}$ b示して岕万が，溶接継 手とは見かけの切欠感受性が異なっているように思わ れ，これは次のように説明される。本報告で考えている ような $K_{t}$ の筙畔では，同一亀裂長さで龟裂登生寿命を 定義した場合，母材切欠材と溶接継手の鼌裂発生寿命と 全寿命との比はほぼ $0.4 \sim 0.5$ であることから ${ }^{11)}$ ，見か けの切欠感受性が界なっている理由として，龟裂発生後 の亀裂伝ぱ過程に対する切欠の影響の度合が異なってい ることが考えられる。つまり，母材切欠材のような貫通 亀裂の場合，初期切欠先端半径程度まで急㤠が成長する と初期切欠の影響は無くなるのに対し ${ }^{16)}$ ，本報告のよう に外部欠陷としての余盛がある溶接継手では表面亀裂と なり，板厚の 20\% 30\% 程度までその影響があるとさ

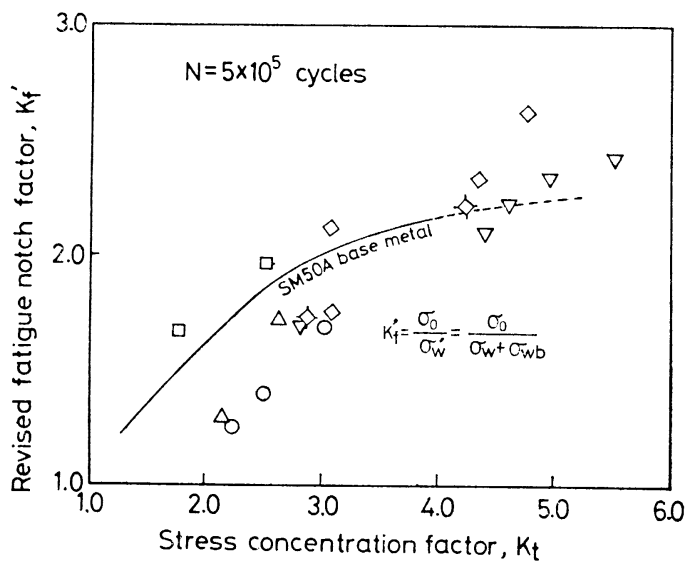

Fig. 18 Relationship between $K_{f}^{\prime}$ and $K_{t}$

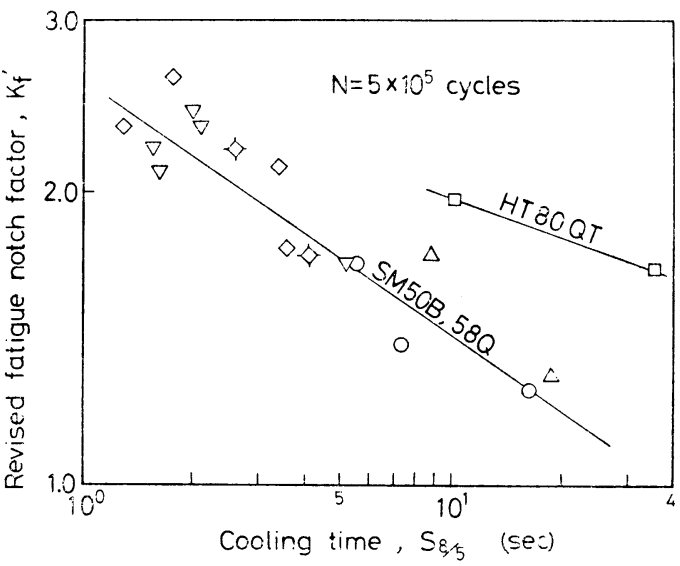

Fig. 19 Correlation between $K_{f}^{\prime}$ and the cooling time due to Eq. (5)

れており 122,13)，亀裂伝ぱ寿命のかなりの部分が止端部の 忘力集中の影響を受けることになり，結果として図に示 されるような直線的な相関が得られたものと考兄られ， このことは余盛のある溶接継手の場合を考虑すると, 倱 裂云ぱ過程を含まない亀裂発生寿命で，切欠感受性を評 洒すべざあることを示崚しているものと思示れる。

Fig. 19 には，（5）武ふら求めた冷却時晶と $K_{f}^{\prime}$ との 関倸を示した。これは Fig. 17 と同様な傾向を示し，こ れから溶接止端に括るる応力集中に起因する溶接継手の 波れ強さの低下を最小限にするような適正溶妾条件の設 定が必要となる。本報告は，被覆アーク溶接，下向姿勢 という限られた枠内であるが, SM 50 B および SM 58 Q の場合, 溶接設計の段階で便宜的に, 溶接最䅂層のボン ド部に拈ける $800^{\circ} \mathrm{C}$ から $500^{\circ} \mathrm{C}$ までの冷却時間を 6 $7 \mathrm{sec}$ 以上にすることにより，Fig. 4 におけるリブ十字 継手や十字継手の疲れ強さを突合せ継手と同程度まで改 善することができることを示唆しており，本報告では入 熱条件を継手の種類，寸法によらず一定としたことが， 結果として止端形状を劣化させ，さらに疲れ強さを低下 させたものと考えられる。

以上のように, 溶接継手の疲れ強さは溶接止湍形状を 介して溶接条件により支配されることを統計的に明らか にした。しかしながら, 実際の構造物では溶接法や溶接 技能等により，溶接条件も多様に变化することが考えら れる。著者らは現在，ガスシールドアーク，サブマージ アーク溶接継手についても溶接条件を種々変化させ，同 様な研究を行って扣り，それらの結果も合わせ，今後さ らに検討を加えたいと考えている。

\section{5 結論}

溶接搆造用鋼 SM 50 B, SM 58 Q および HT 80 QT 材 の各種溶接継手について，その溶接止端形状と疲れ強さ 
との関係を統計的に検討した。また，限定された範囲内 ではあるが，溶接条件による止端形状の变化を介して， 溶接条件の疲れ強さへの影響についても考察した。得ら れた結果を以下に示す。

（1）溶接継手の疲れ強さの変動は，継手の種類によ らず疲労限以外では，ほぼ正規分布とみなすことができ た。その変動係数は, SM 50 B 材の場合, 突合せ継手で $6.2 \% \sim 8.7 \%$ ，す及肉継手で $6.7 \%$ 9. $4 \%$ となってお り，母材よりも溶接継手の方が $50 \%$ 程度変動係数が大 きかった。一方，破断寿命の分布は変動係数 $0.13 \sim 0.25$ の対数正規分布とみなすことができた。

（2）亀裂発生点の応力集中係数 $K_{t}$ を，フランク角 の補正を行った Heywood の実験式を用いて計算した。 それらは，Kt-1 として対数正規確率紙上にプロットす ると良い直線関係を示し，その变動伱数は注ぼ $0.4 〜 0.6$ であった。

（3）疲れ強さと溶接止端形状との関倸を, 材種, 継 手の種類，寸法等で分類したグループ間の疲れ強さの变 動とグループ内の変動とに分けてそれぞれ検討した。グ ループ間の疲れ強さの変動は止端部の応力集中と, 角変 形，目違いによる曲げ応力との相乗効果により $87 \%$ ま で説明できる。個々の試験片について行ったグループ内 の疲れ強さの变動に対する $K_{t}$ の寄与は低く，これは試 験片を代表する $K_{t}$ のとり方に問題があると考えられ る。

（4）上述のグループ間の疲れ強さの変動に及ぼす溶 接条件の影響を溶接ボンド部に和ける $800^{\circ} \mathrm{C}$ から $500^{\circ} \mathrm{C}$ までの泠却時間 $S_{8 / 5}$ をパラメータとして用い検討した。 その結果, $S_{8 / 5}$ が $5 \sim 10 \mathrm{sec}$ 以下では $\rho / t$ が急激に小さ くなり，止端部の $K_{t}$ が大きくなっていた。

（5）上記のことから，被覆アーク溶接，下向姿勢と いう限られた枠内であるが，溶接継手の疲れ強さは溶接 止端形状を介して，溶接条件により支配されていること が明らかになった。今後は，他の溶接法あるいは溶接技 能等を考慮した検討が必要と考兄られる。

$$
\text { 謝辞 }
$$

本研究は, 科学技術庁金属材料技術研究所疲れ試跧部 で作成している「溶接継手の疲れ特性データシート」の 結果 ${ }^{17)}$ の一部をまとめたもので，その計画実行の細部や 溶接䊝手圾験材の製作方針について御助言いただいてい る金材技研瘵れデーダシート検討会第 2 分科会の委員の 方々に感謝いたします。また，まとめに当たって図表の 整理をしていただいた金村技研 今野武志技官に厚く謝 意を表します。

$$
\text { 文献 }
$$

1）たとえば，溶接継手の疲れ強さに関する実験的研
究, JSSC, Vol.7, No.72 (1971) $17 \sim 38$.

2）たと党ば，二瓶正俊，佐々木悦男：SM $50 \mathrm{~A}$ 銓突 合せ溶接継手の疲れ強さのばらつきと余盛形状に ついて, 溶接学会誌, Vol. 45, No. 1 (1976) 54 $\sim 60$.

3）たとえば，溶接継手の止端研削に上る疲れ強さ向 上法, JSSC, Vol. 12, No. 126 (1976) 1 22.

4）たとえば, S. Kado, T. Ishiguro, M. Hanzawa, H. Yokota : Influence of the Conditions in TIG Dressing on Fatigue Strength in Welded High Tensile Strength Steels, IIW Doc. -XIII-771-75 (1975).

5）吉田進，稲垣道夫，金尾正雄，佐々木悦男，二瓶 正俊，鎌倉将英：SM 50 B 突合せ溶接継手の疲れ 特性飞拈上ぼす寸法・速度効果, 溶接学会誌, Vol. 47. No. 9 (1978) $627 \sim 632$.

6）鎌倉将英，二瓶正俊，佐々木悦男，金尾正雄，稲 垣道夫：SM 50 B リブ十字す久肉溶接継手の疲れ 特性におよ注す寸法効果, 溶接学会誌, 投稿中.

7) T. H. Topper, R. M. Wetzel and JoDean Morrow : Neuber's Rule Applied to Fatigue of Notch Factors, J. of Materials, Vol.4, No.1 (1969), 200.

8）西島敏, 竹内悦男: 溶接構造用 SM $50 \mathrm{~A}$ 鋼の確 率疲労特性, 材料, Vol. 27, No. 300 (1978), 884 $\sim 889$.

9）鋼船規則，日本海事協会 (1975).

10) R. B. Heywood : Designing by Photoelasticity, 177, Chapman \& Hall Ltd (1952). 西田正孝：応力集中，森北出版（1967）.

11）二瓶正俊, 今野武志, 佐々木悦男: 龟裂発生寿命 に及注す切欠形状の影響, 日本造船学会論文集, Vol. 144 (1978), 323 333.

12) T. R. Gurney : Finite Element Analyses of Some Joints with the Welds Transverse to the Direction of Stress, Weld. Insti. Members Report, E/62/75.

13) P. Albrecht and K. Yamada : Rapid Calculation of Stress Intensity Factors, J. of the Structural Division, ASCE, Vol.103, No. ST2 (1977) $377 \sim 389$.

14）榉垣道夫, 中村治方, 岡田 明 : 溶接部の泠却時 間の推定に関する実験式の理論的検討，金属材料 技研報告, Vol.8, No.2 (1965) 124 141.

15) E. Sasaki, A. Ohta and M. Kosuge : Notch Sensitivity in Fatigue of Several Structural Materials, Trans. NRIM, Vol.20, No.2 (1978) $128 \sim 137$.

16）西谷弘信，石田誠：主軸端にき裂をもつだ円孔 の引張りに打ける応力桩大俰数, 日本機㭜学会論 文集, Vol. 39, No.317 (1973) 7 14.

17) NRIM FATIGUE DATA SHEET, No. 5 (1978) SM 50 B リブ十字, 十字, SM 58 Q, HT 80 QT については 1979 発刊予定 